\title{
Intercultural Competence and Skills in the Biology Teachers Training from the Research Procedure of Ethnobiology
}

\author{
Geilsa Costa Santos Baptista*, Geane Machado Araujo
}

${ }^{1}$ Department of Education, State University of Feira de Santana, Feira de Santana City, Bahia State, Brazil, ${ }^{2}$ Department of Biology, State University of Feira de Santana, Feira de Santana City, Bahia State, Brazil

*Corresponding Author: geilsabaptista@gmail.com

\section{ABSTRACT}

We present and discuss the results of qualitative research based on a case study with biology undergraduate students from a public University of Bahia state, Brazil. The objective was to identify the influence of practical experiences involving ethnobiology applied to science teaching on intercultural dialogue into their initial training. To collect data, undergraduate students were asked to construct narratives revealing the influences of ethnobiology into their training as future teachers. Data were analyzed according to Bardin (1977) and supported by specific literature from the fields of science education and teaching. The thematic categories generated lead us to conclude that the undergraduates of biology teaching made reflections that allowed them to build opinions with meanings that should influence their pedagogical practices with intercultural dialogue. We recommend further studies involving ethnobiology and the training of biology teachers, with a larger sample of participants and the methodological and theoretical procedures of this science. Improvements could be made in biology teacher education curricula that encourage respect and consideration of cultural diversity. We highlight that it is imperative for teacher education courses to generate opportunities for on-site practical experience, in addition to the theory used in the classroom.

KEY WORDS: ethnobiology; initial teacher training; cultural plurality; dialogue; prospective teachers

\section{INTRODUCTION}

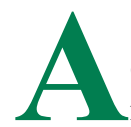

s schools and science classrooms become increasingly culturally diversified, teacher training programs need to generate opportunities to develop skills and abilities to meet varied needs and expectations of students and to communicate science and its products. It is necessary in the context of school education, for teachers to develop the competencies and skills that will enable them to teach Western science without, however, losing sight of the consideration and respect of their students' knowledge plurality and practices, which are representative of their cultural diversity. Bennett and Bennett (2004) define cultural diversity as differences in values, beliefs, and behaviors learned and shared by groups of people in interactions defined by nationality, ethnicity, gender, age, physical characteristics, sexual orientation, economic status, education, profession, religion, affiliation organization, and any another grouping that generates identifiable patterns.

To Lederman et al. (2001), people need to master science to the full inclusion and exercise of their citizenship. This is not only for scientifically and technologically influenced societies, but also those non-scientific societies which have developed over thousands of years. These societies are still developing and have thought systems which have enabled them to live and sustain their natural resources for past, present, and future generations. Many indigenous societies around the world still exist in close relations with the nature of their environment.
According to the American Anthropologist and biologist, Darrell Addison Posey (1997), one of the precursors of ethnobiology, the study of knowledge and concepts developed by any society and its cultures related to biology is called ethnobiology. Ethnobiology is the study of the relationships that humans, as cultural beings, constitute with other living beings, including their knowledge and practices in a past and present perspective.

Ethnobiology has contributed to countless new studies within biology, such as school education. Baptista (2007, 2012) was the first researcher to develop explicit investigations about ethnobiology's contributions to teaching, learning, and science teacher training. She argues that ethnobiology is an important path for intercultural teaching because it helps teacher's training to be culturally sensitive to be attentive to the cultural diversity present in classrooms through their research and understanding for developing intercultural dialogue. Intercultural dialogue in science classrooms is a communication relationship between the culture of science and the students' cultures. In this relationship, the knowledge carried by the individual, which is derived from his/her socio-cultural universe, is exposed and considered according to their own, original context, and applicability (Lopes, 1999).

In intercultural dialogue, there is respect for cultural diversity. There are no attempts at hierarchization as the individuals involved have their cultural identities valued, and their visions 
of nature expanded with scientific knowledge, instead of attempts to cancel them, as is often the case of pedagogical practices based on conceptual change (Posner et al., 1982). Teaching strategies of the conceptual change's model seek to create conditions in which students feel dissatisfied with their previous conceptions. To do so, the teacher must cause the individuals, through manipulation of conflicting situations, to see the scientific conceptions as intelligible and simultaneously more plausible than their previous conceptions.

We present and discuss the results of qualitative research based on a case study involving undergraduate students in biology teaching of the State University of Feira de Santana (UEFS), Bahia, Brazil. This research aimed to analyze the influence of practical experiences involving the ethnobiology on the initial training of biology teachers for the development of intercultural competence in the formation of prospective teachers. The study attempted to answer the following question: If we apply ethnobiology to the initial training of biology teachers (undergraduate students), can this increase their sensitivity to cultural diversity?

It was based on the premise that it is imperative for higher education institutions to offer opportunities for future teachers to reflect and develop the skills and abilities to operate efficiently in culturally different contexts (Ochoa et al., 2016). The cultural diversity present in today's classrooms challenges teachers to change traditional teaching strategies for innovative pedagogical practices, requiring understanding of how diverse cultures see and conceive nature.

\section{CULTURAL DIVERSITY ON SCIENCE TEACHING CONTEXT AND ETHNOBIOLOGY'S AIDS}

According to Nicolescu (2015), the term globalization emerged in the late 1960s and was coined by a Canadian expert in mass media theory, Professor Marshall McLuhan of the University of Toronto. To Nicolescu, the term arose as a "global state," resulting from the awareness that the world is in the process of transformation from a single economic, political, and socio-cultural system, and the implications of this phenomenon are seriously inconclusive.

In the school context, Carter (2007) argues that as a result of the quick globalization and the world's complex transformations resulting from it, including migratory factors, the classrooms of schools around the world have become increasingly heterogeneous from cultural standpoint, thus impelling it, to the strong need to prepare people to act in progressively scientific and technologically influenced societies. This, in turn, has aroused the growing interest of science education educators about teaching and the construction of scientific knowledge concerned with the coexistence between science and other ways of knowing (Carter, 2007), to broaden, and not nullify the visions of nature with scientific ideas.

As a way of awakening in students of different cultures, the contextualization of scientific knowledge and negotiation of their meanings in their contexts of origin and applicability and, consequently, their interest in science, Meyer and Crawford (2011) propose teachers teach science as a cultural way of knowing that can relate to other knowledge systems. To this end, Meyer and Crawford point to the need to adopt classroom-based research strategies that lead students to experience scientific work but argue that such adoption alone is not enough, needing innovations in this regard.

In pragmatic terms, we understand that bringing science closer to students requires going beyond the classroom and the science epistemology to include other knowledge systems in which these individuals are embedded. This, in turn, requires contact with these subjects' cultural realities, into their social spaces of experience, where local knowledge is investigated and understood to, later or in parallel, establishes connections with scientific knowledge, either in terms of similarities or epistemic differences (Baptista and El-Hani, 2009). It is important to highlight that when we talk about relationships of similarities and/or differences between knowledge, we are not in any way, trying to hierarchize any cultural system of knowing, but rather to find opportunities for dialogue between cultures to be established in classrooms, involving both teachers and students. The dialogue opens spaces for the interlocutors to present their thoughts and knowledge, which come from epistemic patterns of specific contexts.

Research by Baptista (2007), for her master's degree, revealed interesting results on the investigation of students' cultural knowledge in socio-cultural contexts. Observations during her teaching experience in a public school in the Bahia state, Brazil, indicated pedagogical practices concerned solely with the transmission of scientific knowledge, thus not contributing to the expansion of students' knowledge who were farmers and attended that school. Baptista realized that the school was not preparing them for the appreciation of their cultural identities and mastery of scientific knowledge that would help them make decisions in view of the difficulties they experienced. These students faced significant problems related to agricultural pests and soil impoverishment, and in many cases driven to rural exodus by survival difficulties. Baptista's research also revealed that ethnobiology could contribute to reverse this situation by supporting teaching and learning, through its theoretical frameworks and methodological research procedures, be necessary, however, a teacher education sensitive to cultural diversity. Teacher training, either initial or continuing, attentive to students' cultural universes, seeking to investigate, understand, include, and value their knowledge and cultural practices in the classroom through dialogues with the scientific culture is an object of teaching and learning.

To Baptista (2007), science teachers can use ethnobiology to investigate and understand students' cultural knowledge linked to nature in two ways. First, using methodological procedures in the classroom, field, or communities from which students come (such as ethnographic techniques: Interviews, comments, drawings, or video recording), and second, through literature containing ethnobiological knowledge of a community. 
Teachers can develop and apply didactic sequences and resources based on intercultural dialogue, between the scientific knowledge taught and the students' cultural knowledge, with the possibility of establishing numerous relationships, whether of similarities and/or differences in relation to its epistemology.

Collaborative partnerships are needed to share theoretical and practical aspects involving ethnobiology and school education so that teachers, researchers, and students understand how the hegemonic and colonial culture prevailed and still predominates the school universe. These partnerships are also needed in organizing the pedagogical discourse of teaching and learning with Western science as not the only legitimate way to produce and use knowledge valid for humanity around the world. Science as dominant cultures within educational spaces, which in turn, ranks other modes of knowledge, which has their own ontologies and epistemologies. Especially in Latin American schools, which serve students from traditional communities such as artisanal fishermen, shellfish farmers, farmers, caiçaras (the traditional inhabitants of the coastal regions of the Southeastern and Southern Brazil), quilombolas (Afro-Brazilian resident of settlements established by escaped slaves from slave plantations that existed in Brazil until abolition in 1888), and indigenous, among others, who have suffered, and still suffer, since the colonization periods, discrimination and devaluation of their knowledge, and traditional practices.

Regarding teacher training in Brazil, it should be noted that there have been three basic perspectives. First, up until the 1970s, the technical rationality, for which the teacher's activity was above all, as instrumental, directed to problem-solving through the application of scientific theories and techniques rigorously, without any reflection or interference of their pedagogical knowledge (Krasilchik, 1987). Second, the practical rationality, which began in the 1990s, presupposes the teacher as a researcher, who questions his/her practice and, based on this questioning, makes reflections. In this model, the teacher goes from being a mere task executor and transmitter of knowledge to becoming a researcher (Schön, 1992). Teachers' research contributes to reflection, and vice versa, as well as to build a personal way of knowing and advancing their knowledge (Schön, 1992). Finally, the third and current perspective, the critical rationality, strongly adopted since the 2000s, starts from the premise that the teacher, as in practical rationality, is a professional who problematizes, but differs from it because in addition to problematizing and investigating, he/she plans and modifies their own learning, which requires dialogues involving subjectivities and other aspects of the social and cultural contexts of education (Diniz-Pereira, 2014).

\section{METHODOLOGY}

\section{Research Approach and Students' Sample}

This study was based on a qualitative approach and case study (Martins, 2004; André, 2013) that was developed in the first semester of 2016 and 2018 at the State University of Feira de Santana (UEFS).
The research sample involved 18 biology teaching undergraduate students (BTU students), both male and female, between 17 and 29 years of age, enrolled in the discipline Cultural Pluralism and School Inclusion (EDU 354), a component of the Biology Teaching course of UEFS. The course goal, described on the website in January 2017 ( http://www1.uefs.br/portal/ colegiados/ciencias-biologicas), was to train teachers to work efficiently in the Brazilian basic education system, in natural sciences teaching (fundamental level or elementary school, students aged 11-14 years old) and biology teaching (middle level or high school, students aged 15-17 years old).

The biology teaching course is divided into eight semesters over 4 years. EDU 354 is offered in the third semester and has a total workload of $75 \mathrm{~h}$ distributed in $5 \mathrm{~h}$ a week. The total workload assigned to the activities related to this research was 40 h. The EDU 354's content consisted of: The school as socio-cultural space; reflection on the individuals' diversity; production of biological knowledge of gender's issues, body, and sexuality differences; the relationship between science and other ways of knowledge in the educational domain; and exploring cultural borders in biology learning in different educational contexts. Regarding the cultural diversity approach of EDU 354, it is important to note that its content was determined by Brazilian public legislation (Brazil, 1996, 1997, 2003a, 2008), which, in general, states that the schools of the country must attend the various cultural manifestations and consider the impossibility of one culture being judged superior to another, thus promoting a peaceful coexistence.

\section{Practical Experiences with Biology Undergraduate} Students Involving Ethnobiology

EDU 354's professor (first author of this paper) offered several lectures about ethnobiology to the students, its concepts, history, approaches, applicability, methodological research procedures as well as its ramifications and examples. This was to provide the BTU students with some knowledge about ethnobiology's practices in science teaching. Research techniques of ethnobiology and its ramifications received emphasis in science teaching considering the broader objective of the EDU 354 practical component. It was described that ethnobiological studies are focused on several fields, such as ethnobotany, ethnozoology, ethnopharmacology, and ethnomycology, among others and may have two different approaches: Utilitarian and intellectualist (Berlin, 1992).

The utilitarian approach questions how human societies use nature, while the intellectualist approach tries to understand how human societies view or conceive nature. An example of a utilitarian study is the research of Costa-Neto (2011) on animals as medicinal resources in the Bahia state, Brazilian Northeast. Prado (2012) is an example of an intellectualist study based on the knowledge of the eating habits of large wild mammals in the Vale do Ribeira Quilombola (São Paulo state, Brazil).

It was also explained to students that ethnobiological research is based on ethnoscientific studies and ethnographic techniques. Ethnoscientific studies investigate all the knowledge that 
a cultural group has about the social and natural universe, as well as about itself (Toledo and Barrera-Bassols, 2009). Research procedures in ethnobiology may include techniques such as observations, interviews, questionnaires, images, and drawings, among others.

The presentations sought the individuals' participation, letting them to explore their previous knowledge of ethnobiology. To expand the students' knowledge about this topic, they were also assigned to read and discuss references in the classroom, from Baptista (2007, 2015) and Marques (2002). Later, the BTU students were divided into two groups: Ethnobotany and ethnozoology. Both groups were reorganized in teams of three students, resulting in six teams (Table 1). Each team received a function to explore within the main ethnobotany-ethnozoology division: Nutritional, medicinal, and artisanal, Table 1.

The teams received their first task. Each one had to select one teaching topic that could be either natural sciences or biology content and to prepare a questionnaire protocol for semi-structured interviews with vendors at a local traditional market. The interviews aimed to identify local knowledge and to establish relationships of similarities and/or differences with the scientific knowledge of natural sciences or biology taught in schools (Baptista, 2007).

EDU 354's professor provided two questions to the teams, as examples and a basis for their reflection to guide their protocol constructions (but it was not mandatory to incorporate on the protocol). First, what do the vendors of a traditional market know and practice about plants or animals sold by them? Second, what relationships of similarities and/or differences could be established between that knowledge and the topics discussed in the natural sciences and biology classrooms?

\section{Table 1: Distribution of biology teaching undergraduate} students by teams

\begin{tabular}{lll}
\hline Applicability & Ethnobotany & Ethnozoology \\
\hline Nutritional & 3 students & 3 students \\
Medicinal & 3 students & 3 students \\
Artisanal & 3 students & 3 students \\
\hline
\end{tabular}

Considering that the objective of this paper is not to present all the interviews conducted, we will transcribe only one of each team's questionnaire protocol: Team 1 (ethnobotany nutritional): Why are the vegetables you sell humidified with water? Team 2 (ethnozoology nutritional): What are the names of the animal parts you sell? Team 3 (ethnobotany medicinal): Which medicinal plants do you sell and what are they for? Team 4 (ethnozoology medicinal): What is the name of the animal that you use and recommend as medicine and for what illness? Team 5 (ethnobotany artisanal): Which kind of plant do you use more for your artisanal products and how do you get it? Team 6 (ethnozoology artisanal): What is the cultural significance of the owl that you sell?

After having developed the questionnaire protocols, the students together with their professor and the discipline's teaching assistant (the second author) chose the Centro de Abastecimento de Feira de Santana City Supply Center of Feira de Santana (CAFS), a popular space, as the best place to study and develop the interviews (Figure 1).

Feira de Santana city is located $116 \mathrm{~km}$ from Salvador, the capital of Bahia state. It is a semi-arid region of the Brazilian Northeast, representing the local and regional culture. The main ecosystem of the region is the Caatinga, characterized by problematic socioeconomic and environmental conditions. Its climate is dry and hot, between $25^{\circ} \mathrm{C}$ and $35^{\circ} \mathrm{C}$ on average. Low rainfall levels inhibit agriculture and livestock, which is the main income and livelihood source of its rural population, generating unemployment, and poverty. Despite this harsh reality, the population of the Brazilian Northeast still maintains their cultural traditions, from the European colonization, influenced by the ethnic and cultural miscegenation between indigenous, African, and Portuguese inhabitants, in addition to other minorities who were formed during the long Brazilian history. These traditions are kept in various forms, such as oral narratives, literature, songs, dances, celebrations, garments, artifacts, religions, or culinary, and may involve natural and non-natural elements as well as the human imagination.

In the CAFS, vendors sell products such as fruits, vegetables, poultry, seafood, and products for multiple purposes. In

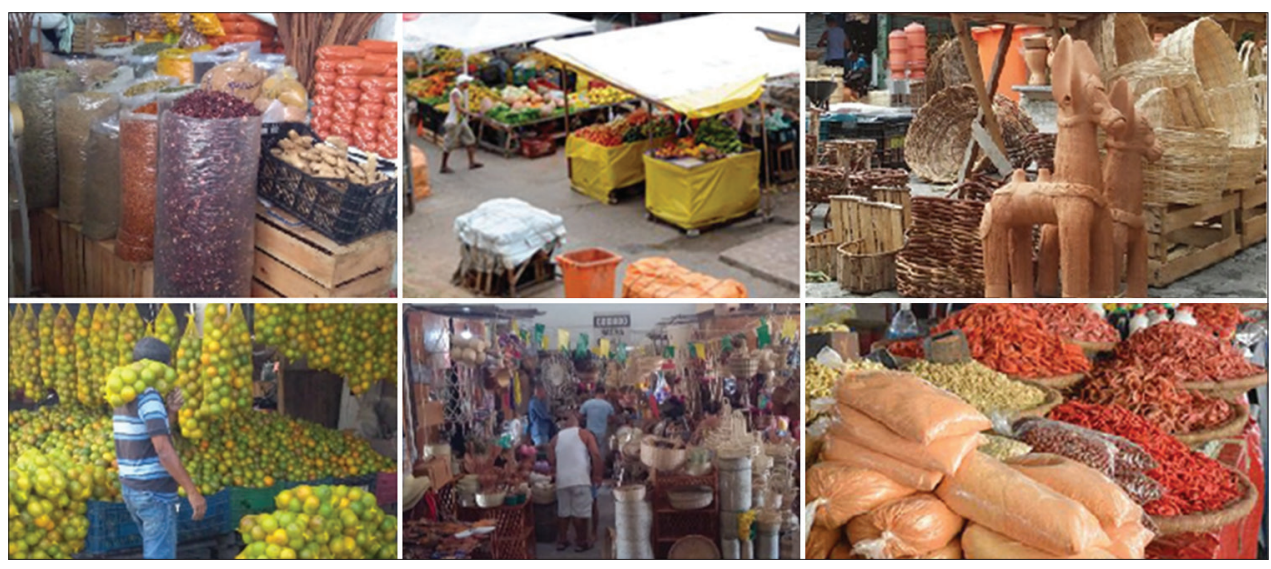

Figure 1: Partial views of the City Supply Center of Feira de Santana. Source: Retrieved by the second author during the primary stage in 2017 
addition, amulets made from animals such as the Ferruginous Pygmy owl (Glaucidium brasilianum); drugs made of animals, such as the jibóia (Boa constrictor), and plants, such as umburana (Amburana cearensis) a Brazilian Northeast endemic species. Items made of cowhide and plants, such as sisal (Agave sisalana), used for making handbags, luggage, shoes, hats, or rugs are also sold here. Thus, the CAFS was chosen mainly because it involved workers who sell products that reflect distinctive cultural aspects of the region. These sellers certainly could be parents or students of the elementary school, in fundamental or middle levels. The CAFS also was chosen because of its central location in the city of Feira de Santana, which could enable the participation of BTU students.

Teams organized two visits to the CAFS, each one of $4 \mathrm{~h}$ long to follow ethnobiological research procedures. The purpose of the first visit was to observe and establish initial contacts with the community, establishing a rapport and a sense of trust. The goal of the second visit was to conduct semi-structured interviews. Interviews had to be developed following the previously established questions. Data was recorded in two ways: one, in a field journal and two, by filming or audio recording the interviews, depending on the responsiveness of each participant. The vendors were informed by the students that the interviews would be recorded (using a video camera, a cellphone, or a digital recorder) and that they could agree or refuse to participate in these recordings. They were also informed that data collected would be used for didactic resources and sequences by BTU students, contributing to their training and teaching of natural science and biology that respects and considers the diversity of cultural knowledge. Each vendor received a consent form that must be signed to participate, following the Brazilian current legislation on researches with human beings (Brazil, 2003b).

At the end of their activities in the CAFS, the BTU students returned to their homes with the assignment to transcribe their interviews and present them to the class a week later. They also were asked to select textbooks of natural sciences and biology as well as scientific texts of ethnobiology that contained educational subjects of their choice.

A week later, the undergraduate students were back in the classroom and sought to establish relationships between the local knowledge of the vendors and scientific knowledge. They consulted textbooks of natural sciences, biology, and the specialized scientific literature in the field of ethnobiology previously chosen by them. At that time, dialogues were opened with the professor's guidance to facilitate the establishment of these relations.

The next step was to prepare resources and a didactic sequence for intercultural dialogue regarding ethnozoology and ethnobotany. Those resources and didactic sequences were presented in the classroom by each team. The moment allowed to raise and discuss various questions, to engage in problematization, to make suggestions, to exchange pedagogical ideas and knowledge regarding the natural sciences and biology teaching through dialogues, in a way to be sensitive to cultural plurality. The authors made observations and reflections recorded in a field diary. The objective here was to increase understanding of how an activity involving ethnobiology could contribute to the initial training of the biology teacher.

\section{Data Collection and Analysis}

After having presented their resources and didactic sequences, all BTU students were invited to write a narrative based on the question: How did the activity involving ethnobiology, investigation of cultural knowledge as well as the production of resources and a didactic sequence contribute to your initial training in cultural diversity in science and biology classrooms? What we meant by a narrative was a description of facts, events, or a story. The narratives were expected to be about the students' experience with the CAFS sellers, construction of resources and didactic sequences, and in an associated way, explanations about how ethnobiology could contribute to their training as future biology teachers. To guarantee the students' privacy, we asked them to give their answers anonymously.

Data were analyzed according to Bardin (1977), to whom a text is a means of expression of the subject. In the content analysis of a text, the researcher sought to categorize units of a text (words or phrases) that was repeated, inferring expressions that represent these units. Thus, in the analysis by thematic categories it was possible to find meanings grouped according to what they have in common. In the study presented here, the analysis of the narratives sought to select thematic categories containing the meanings attributed by the BTU students to their experience during the practical component of EDU 354, which involved ethnobiology applied to the teaching of natural sciences and biology. On these analyzes, discussions were held with the support of specific literature on the areas of education and science teaching.

\section{RESULTS AND DISCUSSION}

Of the 20 BTU students enrolled in the EDU 354 course, two dropped out for unknown reasons. Thus, 18 undergraduate $(n=18)$ students participated in this study. Instead of writing the narratives required by the professor, the students presented direct answers to the question given to them. This could happen either because they did not understand the meaning of a narrative or because they preferred not to describe their experiences during the activities. From the analysis of the answers of the students, it was possible to create four thematic categories. Each category will be illustrated with excerpts from the answers of some students as examples followed by discussions.

\section{Category 1: Perception of the Existence of a Diversity of Cultural Knowledge in the School Environment}

When teachers perceive the school space as multicultural, they adapt their educational proposals to the realities of the subjects that are present in these spaces, sharing knowledge, and promoting peaceful coexistence between different cultures (Gomes, 2003). It is possible to provoke affective reactions that guide acceptance and interaction behaviors with other 
individuals perceived as different. After their participation in the activities involving the interviews with sellers of the CAFS, BTU students perceived the existence of this multiplicity of cultures in classrooms, as can be seen in the following two statements.

This activity helped to develop a broader view of biology and how popular knowledge will always be present within the school environment. Working directly with the knowledge of the sellers improved the understanding of many aspects of our culture. Brainstorming, choosing resources, and creating a didactic sequence helped us develop various skills as teachers as we must organize the data collected, make plans, and give classes.

It helped to learn new content. Having observed cultural knowledge of selected citizens, we can conclude that each of them has a different culture, customs, and knowledge, just like in biology classrooms, we have students who have different cultures and coming from their homes with previous knowledge. As teachers, we should use this to our advantage and adapt our teaching.

The fact that BTU students identified the classrooms as multicultural spaces is an excellent indicator that the activity involving theoretical and methodological aspects of ethnobiology caused reflections that may influence their future pedagogical practices. It should be especially helpful in investigating students' previous knowledge about natural phenomena and in developing and applying strategies of teaching and learning focused on intercultural dialogue. This will certainly contribute to the motivation of students' participation, since opportunities will be generated to speak up about their knowledge that is inherent to their sociocultural reality. However, it is believed that these strategies must be practiced actively, avoiding the passivity of the subjects as it happens frequently during the activities directed at simple transmission of scientific contents (transmissive pedagogy).

It is necessary to use strategies involving problematizations and a search for solutions, such as games, dramatizations, film exhibitions, and to increase subjects' motivation with technological resources, such as computers and cell phones. The aim should always be active participation, being aware of scientism, which has Western science as the dominant culture and the only one to be presented in classrooms, enforcing the idea that Western science best answers the humanity's questions. In addition to modern Western science, there are other ways of knowing that can and should be respected, according to their own criteria of origin and applicability.

Category 2: Respect for the Diversity of Students' Knowledge and the Importance of Relating that Type of Knowledge to Scientific Knowledge

According to Lee (2001), as the student population in different countries becomes more diverse culturally, educators are increasingly aware of the need to teach Western science to all students - as traditionally practiced in the scientific community and taught in schools - so that they can actively participate in scientifically and technologically influenced societies, and, at the same time, respect the different languages and cultures that these subjects bring with them to the science classroom. However, as emphasized by Tala and Vesterinen (2015), students need to develop an understanding of how science works and scientists operate, which requires an approach to the nature of science, especially history, philosophy, and sociology of science.

Regarding respect for the diversity of cultural knowledge on nature, ethnobiology can certainly help teachers, since one of its objectives is to investigate, understand, and elucidate the knowledge that different cultures have about the natural world (Baptista and El-Hani, 2009). BTU students understood this objective when carrying out didactic activities involving ethnobiology. The following responses demonstrate this "...Ethnobiology has contributed to my understanding and respect for cultural knowledge," and "...I understood that my role in the classroom is to recognize, respect and understand the culture of individuals and to make others in the classroom do the same."

The participants also pointed out that this science fosters the understanding that students' cultural knowledge can be related to the scientific knowledge in the moments of teaching and this will contribute to the expansion of their worldviews, as can be seen in the following "...I understood that we should respect the ideas of common sense, the knowledge brought by the students. My role <...> is only to inform students a new way of looking at natural processes, without criticizing, despising or disregarding the students 'knowledge," also " $<$... $>$ it helped me understand that each individual carries with him or her cultural knowledge, which should not be ignored or considered as wrong, but instead, as related to scientific knowledge."

For BTU students, establishing relationships between students' cultural knowledge and the scientific knowledge explained in school makes the teacher able to work with scientific knowledge minimizing conflicts that may occur in classrooms "... it showed a way in which I can relate popular and cultural knowledge to scientific knowledge and can also reconcile them to know how to apply certain subjects in the classroom without causing any conflicts," and:

I could see that it is possible and necessary for the teacher to associate the contents of the biological sciences with the knowledge brought by the students culturally, so that the student broadens his or her worldview, understanding the subjects without conflicts with their cultural knowledge.

The possibility of conflict pointed out by the undergraduate students can be understood as something important to their training in science teaching based on a dialogue between cultural knowledge. We start with the premise that dialogue in science education is not interested in simple confrontation or hierarchies (that is, in contestation or a dispute over superiority between conflicting cultural ideas), but rather in the exposition of ideas as a means of comparing students' ideas with scientific 
ideas. As Bohm (2005) argued, the purpose of dialogue is not the judgment of truth but the exploration and understanding of human thought. Dialogues in science teaching are relationships of communication which goal is an exchange of cultural meanings between teachers and students and between students on any given topic that is the object of teaching and learning.

\section{Category 3: Relating Students' Realities to Scientific Learning}

As mentioned before, dialogic relations in science education need to consider the exposition of ideas by the interlocutors. This, in turn, involves different types of languages, including scientific and non-scientific ones. This premise was pointed out in the answers of BTU students, as evidenced by the following "The dialogue involves the scientific language in an interactive way with the students. Thus, it contributes to learning $<\ldots>$ in a meaningful way and the teachers training sensitive to popular knowledge." It can be noted that the undergraduate students realized that the scientific language was present in the dialogue which occurred in science teaching, and, in addition, they emphasized that this language actively interacted with the students.

We understand that it is necessary for teachers to be aware that when representing the scientific language they need to pay attention to the languages used by students (narratives, drawings, images, songs, gestures, facial expressions, etc.), because they reveal knowledge and feelings useful for communicating and constructing scientific meanings in classrooms. It is because the language used by the student can convey the knowledge inherent to their reality.

Among the answers, cases where the scientific language differed from the students' language were identified "The first learning experience was to join popular knowledge with scientific knowledge; although the popular language is different from the scientific language that does not mean that it is wrong." This statement agrees with the literature on science teaching, which deals with discursive interactions in science classrooms. According to Mortimer et al. (1998), the language that students bring to classrooms differs from scientific language. Hence, it is necessary to look at how students express their knowledge and, at the same time, to help them use the language of science, since, as stated by Mortimer et al. (1998), learning science is also about learning to express oneself in scientific language.

The statement quoted above also reveals the understanding that students' language cannot be considered wrong just because it is different from scientific language. Any given discourse, as a component of language, can only be considered correct having in mind the context in which the expressions are used (Leite and Almeida, 2001). Words used in the same speech may have different meanings in different contexts. The teacher may consider a language used by the student in a dialogue to be inconsistent with science, but not as wrong and/or inferior. A language has meaning and significance and exerts the supreme function of representing the worldview of the subject and his/her knowledge. Meaning and significance, in turn, have their own cultural contexts of origin and applicability.

\section{Category 4: Increase in Teacher's Knowledge}

For BTU students, their experience in EDU 354 "Contributed in a significant way to a greater understanding of cultural knowledge $<\ldots>$ which is of fundamental importance for our development," and "...allowing students to realize that there is cultural plurality outside and within the school." Certainly, ethnobiology added to the science teacher training because it provided information on how students who were members of different societies and cultures know and related to the nature around them. The formative activities involving the ethnobiology awoke in the prospective teachers, orientations of science teaching that shaped their knowledge and beliefs about teaching strategies for the learning involving the students' cultural knowledge. This premise is in line with the ideas of Bell and Sexton (2018) that teachers need opportunities to develop strategies that can be brought into the classroom.

The development of new strategies certainly contributes to teacher education, and therefore, it will benefit dialogical classrooms because cultural knowledge can be included and respected according to its origins and contexts of applicability. Through dialogue, teachers, and students can establish numerous relationships between scientific knowledge and students' knowledge without hierarchization (Baptista, 2007).

\section{CONCLUSIONS}

This research carried out with undergraduate biology teaching students of the UEFS aimed to identify the influence of practical experience involving ethnobiology applied to the teaching of natural sciences and biology on the early formation of biology teachers regarding their competence for dialogue of cultural knowledge. The results indicate that ethnobiology contributed to the education of these undergraduate students in the following aspects: Perception of existence of a diversity of cultural knowledge in the school environment; respect for the heterogeneity of students' knowledge and the importance of relating it to scientific knowledge; reduce the gap between students' realities and scientific learning; and increase in teacher knowledge.

Based on our discussions, we conclude that these findings have great relevance for the early education of a science teacher who is culturally sensitive. These discussions show that the students involved in the study engaged in reflections that allowed them to form opinions with meanings that will certainly influence their future pedagogical practices developing cultural dialogue between science and students' knowledge. It also shows that when teaching opportunities are offered with satisfactory strategies and environment (like here, with ethnobiology's strategies for data collection into the socio-cultural spaces of sellers) can be developed substantial competence for intercultural teaching.

After examination of ethnobiology's strategies used with the undergraduates participating in our study, we evaluated 
the use of other techniques as necessary. In addition to the semi-structured interviews and establishing rapport, the following techniques could be used: Direct and participant observation, which could contribute to a better understanding of the daily realities of informants and their activities as well as to the researcher-researched interaction; schematic drawings, which are a kind of non-verbal language, may facilitate the representation of knowledge by those informants who experience difficulties in oral expression; and, photographs, which would help with analyzing images constructed by the research participants of a certain element or phenomenon of nature.

Our study had its limitations due to the number of participants, the work time with the local informants, ethnobiological research strategies, and the application of the resources and didactic sequences with students in schools. Regarding the number of participants and the time involved in the research, we believe that it is necessary to carry out new studies that involve a larger sample and a period longer than a university semester. That kind of study would give us deeper insights into how ethnobiology can contribute to the initial education of biology teachers, as more subjects would give their valuable reflections about this.

BTU students could have applied the resources and didactic sequences that they produced in the classrooms of the schools in the region, as a way of experiencing the first teaching practices based on intercultural dialogue. This absence can be justified by the lack of extended time and accessibility to the plans of the natural sciences and biology teachers who are already working in schools. To reduce this gap and to expand our studies, we intend to propose an analysis of these resources and didactic sequences by another group of students who will enroll in EDU 354. Based on these analyses, these students would be able to make modifications and/or to add new content, objectives and teaching strategies, among other aspects, aimed at intercultural dialogue.

Despite the shortcomings found, we affirm that our study provided the first mapping of possible categories that can group the contributions of ethnobiology to prospective teacher culturally sensitive training. We understand that other studies can be carried out to broaden data generation that could contribute to improvements on the biology teachers' training curricula that encourage respect and consideration of cultural diversity. We will always highlight the premise that it is imperative to teacher training courses to generate opportunities for practical experience in loco beyond the theory used in classroom.

We hope that data presented here may serve as a motivation for other studies involving ethnobiology and the training of science teachers to deal with cultural diversity through intercultural dialogue. The results should be considered not only in the Brazilian educational context but also in other countries where classrooms are characterized by students of different cultural backgrounds.

\section{ACKNOWLEDGMENTS}

The authors would like to thank the Department of Education of the UEFS , Brazil; to the Research Group on Ethnobiology and Science Teaching (GIEEC-UEFS); and the biology teaching undergraduate students of the Department of Biology who participated on the study.

\section{REFERENCES}

André, M. (2013). O que é um estudo de caso qualitativo em educação? What is a qualitative case study in education? Educação e Contemporaneidade, 22(40), 95-103.

Baptista, G. C. S. (2007). A Contribuição da Etnobiologia Para o Ensino e a Aprendizagem de Ciências: Estudo de Caso em Uma Escola Pública do Estado da Bahia [Ethnobiology's Contribution to Science Teaching and Learning: A Case Study in a Public School in the Bahia State]. Master's Thesis in Teaching, Philosophy and History of Science, Salvador: Federal University of Bahia State University of Feira de Santana.

Baptista, G.C.S. (2012). A Etnobiologia e Sua Importância Para a Formação do Professor de Ciências Sensível à Diversidade Cultural: Indícios de Mudanças Das Concepções de Professoras de Biologia do Estado da Bahia [Ethnobiology and its Importance to Science Teacher Training Sensitive to Cultural Diversity: Indications of Changes of Biology Teachers' Conceptions of the Bahia State]. PhD Thesis in Teaching, Philosophy and History of Science, Salvador: Federal University of Bahia State University of Feira de Santana.

Baptista, G.C.S. (2015). Um enfoque etnobiológico na formação do professor de ciências sensível à diversidade cultural: Estudo de caso. [An ethnobiological approach to science teacher education that is sensitive to cultural diversity: A case study]. Ciência and Educação, 21(3), 585-603.

Baptista, G.C.S., \& El-Hani, C.N. (2009). The contribution of ethnobiology to the construction of a dialogue between ways of knowing: A case study in a Brazilian public high school. Science and Education, 18(3-4), 503-520.

Bardin, L. (1977). Análise de Conteúdo [Content Analysis]. Lisboa: Edições. p. 70.

Bell, S.E., \& Sexton, S.S. (2018). Science education professional development for primary/elementary teachers: A tale of two systems. Science Education International, 29(2), 117-123.

Bennett, J.M., \& Bennett, M.J. (2004). Developing intercultural sensitivity: An integrative approach to global and domestic diversity. In: Landis, D., Bennett, J.M., \& Bennett, M.J., (Eds.) Handbook of Intercultural Training. $3^{\text {rd }}$ ed. Thousand Oaks, CA: SAGE. pp. 147-165.

Berlin, B. (1992). Ethnobiological Classification: Principles of Categorization Plants and Animals in Traditional Societies. New Jersey: Princeton University Press.

Bohm, D. (2005). Diálogo: Comunicação e Redes de Convivência [Dialogue: Communication and Social Networks]. São Paulo: Palas Athena.

Brazil. (1996). Leinro. 9394/96 de Diretrizes e Bases da Educação Brasileira [Guidelines and Basis of Brazilian Education]. Brasília: Diário Oficial da União.

Brazil. (1997). Parâmetros Curriculares Nacionais: Pluralidade Cultural, Orientação Sexual [Nacional Curriculum Parameters: Cultural Plurality, Sexual Orientation]. Brasília: Ministério da Educação, Secretaria de Educação Fundamental.

Brazil. (2003a). Leinro. 10639/03 Que Inclui no Currículo Oficial da Rede de Ensino a Obrigatoriedade da Temática "História e Cultura AfroBrasileira", e Outras Providências [That Includes on the National Curriculum the Thematic "Afro-Brazilian History and Culture", and others Determinations]. Brasília: Diário Oficial da União.

Brazil. (2003b). Normas Para Pesquisa Envolvendo Seres Humanos. $2^{\text {nd }}$ ed. [Rules for Researches Involving Human Subjects]. Brasília: Conselho Nacional de Saúde, Comissão Nacional de Ética em Pesquisa.

Brazil. (2008). Leinro. 11.645 Que Inclui no Currículo Oficial da Rede de Ensino a Obrigatoriedade da Temática "História e Cultura AfroBrasileira E indigena" [That Includes on the National Curriculum the Thematic "Afro-Brazilian and Indigenous History and Culture"]. 
Brasília: Diário Oficial da União.

Carter, L. (2007). Sociocultural Influences on Science Education: Innovation for Contemporary Times. Science Education, 92(1), 165-181.

Costa-Neto, E.M. (2011). A zooterapia popular no Estado da Bahia: Registro de novas espécies animais utilizadas como recursos medicinais [The popular zootherapy into the Bahia state: record of new animal species as medicine resources]. Ciência and Saúde Coletiva, 16(1), 1639-165.

Diniz-Pereira, J.E. (2014). Da racionalidade técnica à racionalidade crítica: Formação docente e transformação social [From technical to critical rationality: Teacher education and social transformation]. Revista de Educação e Sociedade, 1(1), 34-42.

Gomes, N.L. (2003). Educação e diversidade étnicocultural [Ethniccultural education and diversity]. In: Ramos, M.N., Adão, J.M., \& Barros, G.M.N., (Eds.), Diversidade na Educação: Reflexões E experiências [Diversity in Education: Reflections and Experiences]. Brasília: Secretaria de Educação Média e Tecnológica. pp. 67-76.

Krasilchik, M. (1987). O Professor e o Currículo das Ciências [The Teacher and the Science's Curriculum]. São Paulo: EPU/EDUSP.

Lederman, N., Schwartz, R., Abd-El-Khalick, F., \& Bell, R. (2001). Preservice teachers' understanding and teaching of nature of science: An intervention study. Canadian Journal of Science, Mathematics and Technology Education, 1(2), 135-160.

Lee, O. (2001). Culture and language in science education: what do we know and what do we need to know? Journal of Research in Science Teaching, 38(5), 499-501.

Leite, M.S.S., \& de Almeida, M.J.B. (2001). Compreensão de termos científicos no discurso da ciência [Comprehension of scientific terms into science speech]. Revista Brasileira de Ensino Física, 23(4), 458-470.

Lopes, A.R.C. (1999). Pluralismo cultural em políticas de currículo nacional [Cultural plurality into the national curricula politics]. In: Moreira, A.F.B., (Ed.), Currículo: Politicas e Práticas [Curriculum: Policies and Practices]. Campinas: Papirus. pp. 59-80.

Marques, J.G.W.(2002). Oolhar(des)multiplicado: O papel do interdisciplinar e do qualitativo na pesquisa etnobiológica e etnoecológica [The (un)multiplied look: the interdisciplinary and qualitative role in ethnobiological and ethnoecological research]. In: Amorozo, M.C., Ming, L.C., \& Silva, S.M.P., (Eds.), Métodos de Coleta E análise de Dados em Etnobiologia, Etnoecologia e Disciplinas Correlatas. Rio Claro: Sociedade Brasileira de Etnobiologia e Etnoecologia. pp. 31-46.

Martins, H.T. (2004). Metodologia qualitativa de pesquisa [Qualitative research methodology]. Educação e Pesquisa, 30(2), 289-300.
Meyer, X., \& Crawford, B.A. (2011). Teaching science as a cultural way of knowing: Merging authentic inquiry, nature of science, and multicultural strategies. Cultural Studies of Science Education, 6(3), 525-547.

Mortimer, E.F., Chagas, A.N., \& Alvarenga, V.T. (1998). Linguagem científica versus linguagem comum nas respostas escritas dos vestibulandos [Scientific language versus common language on writing answers of university candidates]. Investigações em Ensino de Ciências, $3(1), 7-19$.

Nicolescu, R. (2015). The influences of globalization on educational environment and adjustment of national systems. Procedia: Social and Behavioral Sciences, 180, 72-79.

Ochoa, G.G., McDonald, S., \& Monk, N. (2016). Embedding cultural literacy in higher education: A new approach. Intercultural Education, 27(6), 546-559.

Posey, D.A. (1997). Etnobiologia: Teoria e prática [Ethnobiology: Theory and practice]. In: Ribeiro, D., (Ed.), Suma Etnológica Brasileira. Edição atualizada do [Handbook of South American Indians]. $3^{\text {rd }}$ ed., Vol. 1. Petrópolis: Vozes/FINEP. pp. 1-15.

Posner, G.J., Strike, K.A., Hewson, P.W., \& Gertzog, W.A. (1982). Accommodation of a scientific conception: Toward a theory of conceptual change. Science Education, 66 (22), 211-227.

Prado, H.M. (2012). O conhecimento de Agricultores Quilombolas Sobre Forrageio e uso de Habitat por Mamiferos de Grande Porte na Mata Atlântica: Evidenciando a Centralidade dos Ambientes Antropogênicos na Constituição do Etnoconhecimento (Vale do Ribeira, SP, Brasil) [The Knowledge of Quilombola Farmers on Foraging and Habitat use by Large Mammals in the Atlantic Forest: Evidencing the Centrality of Anthropogenic Environments in the Constitution of Ethno-cognition (Vale do Ribeira, SP, Brazil)]. PhD Thesis in Sciences, Ecology of Terrestrial and Aquatic Ecosystems, São Paulo: Universidade de São Paulo.

Schön, D.A. (1992). Formar professores como profissionais reflexivos [Training teachers as reflexive profissionals]. In: Nóvoa, A., (Ed.), Os Professores e A sua Formação [The Teachers and Their Training]. Lisboa: Dom Quixote. pp. 77-91.

Tala, S., \& Vesterinen, V.M. (2015). Nature of science contextualized: studying nature of science with scientists. Science and Education, 24(4), 435-457.

Toledo, V.M.M., \& Barrera-Bassols, N. (2009). A etnoecologia: Uma ciência pós-normal que estuda as sabedorias tradicionais [Ethnoecology: A postnormal science that studies traditional wisdoms]. Desenvolvimento $e$ Meio Ambiente, 20, 31-45. 